\title{
Assessing the Pedagogical Approaches of Social Studies Tutors Instructional Delivery in the Colleges of Education in the Eastern and Greater Accra Regions of Ghana
}

\author{
Lawrence Odumah (Corresponding Author) \\ Department of Social Science \\ University of Education, Winneba \\ Pearl Adiza Babah \\ Department of Social Science \\ Accra College of Education, Ghana \\ Ronald Osei Mensah \\ Department of Sociology and Anthropology \\ University of Cape Coast, Ghana \\ E-mail: ronald.mensah@stu.ucc.edu.gh \\ Clarke Ebow Yalley
}

Faculty of Humanities and Social Sciences Education,

University of Cape Coast, Ghana

Michael Sakyi-Darko

Department of Sociology and Anthropology

University of Cape Coast, Ghana

Received: May 12, 2020

Accepted: Sep. 30, 2020

Published: November 1, 2020

doi:10.5296/jse.v10i4.17656

URL: https://doi.org/10.5296/jse.v10i4.17656

\section{Abstract}

The purpose of the study is to assess the pedagogical approaches of Social Studies Tutors instruction delivery in the Colleges of Education in the Eastern and Greater Accra regions of 


\section{Macrothink}

Ghana. The research design used for the study was a blend of quantitative and qualitative methods in a descriptive survey manner. The stratified sampling technique was used in this study. In all, a sample size of four hundred and eighty (480) Social Studies teacher trainees were chosen for the study. The data collection tools used were semi-structured interview guide and questionnaire. The study revealed that most of the tutors used appropriate pedagogical approaches to the effective teaching and learning of Social Studies. Again, the study revealed that majority of respondents agreed that the pedagogical content knowledge of Social Studies teachers and teachers' teaching-learning strategies significantly enhanced the instructional process in the classroom. It is recommended that teacher training institutions, teacher education division, and universities in Ghana should give appropriate training to teachers in their subject areas to improve upon their pedagogical skills and knowledge.

Keywords: pedagogical approaches, instructional process, CIPP model of curriculum evaluation 


\section{Introduction}

Curriculum experts, guided by national educational philosophy and policy, together with societal demands, scrutinize and select relevant and appropriate subject, content and pedagogical approaches that yield the expected outcomes for national development. A classic example of such selected and adopted subjects in Ghana is Social Studies. Social Studies, according to Martorrela (1994) has its purpose and goal as the preparation of citizens to be competent, reflective and concerned. The purpose and goal of Social Studies has been one of the major factors that have compelled several countries worldwide to adopt it as one of their developmental subjects (Odumah, 2003). In Africa, its introduction was informed by the quest for relevant education (Shiundu and Mohammad, 1998). Social Studies, in essence, has been identified as the subject in the Ghanaian educational curriculum that can serve as the vehicle for equipping students with the requisite skills, knowledge and values as well as dispositions relevant for producing functional and effective citizens (Ministry of Education, 2005); hence the need for the evaluation of its curriculum to ensure the performance and attainment of its purpose and goals.

The essence of the achievement of curriculum objectives is a function of its evaluation process during development. It is the consensus of most curriculum developers that once a developed curriculum is implemented in schools, appropriate evaluation procedures and mechanisms shall be devised to examine the effectiveness of the curriculum in achieving its aims, goals and objectives. The best designed programme in education will invariably fail to have the intended impact and results if it is not properly implemented and evaluated. This means, the degree of implementation of a particular programme will determine the successes or otherwise of the programme outcomes, which is also dependent on evaluation (Ruiz-Primo, 2006). Fullan and Stiegelbauer (2000) are of the view that achieving effective curriculum implementation and evaluation is a complex process. According to them, "implementation consists of the process of putting into practice an idea, programme, or set of activities and situations new to the people attempting or expected to change" (p.65). They further stated that the existence and persistence of people-related problems and challenges in educational change is the single most essential factor that determines the achievement of desired educational objectives.

On the implementation and continuation of reforms, Fullan (1991) again maintains that most attempts at educational reforms do not succeed not only due to lack of good materials, ineffective in-service training or minimal administrative support but partly, due to the poor assumption of planners and also some problems that are inherently solvable. This means the success story of every curriculum implementation is a function of multiple factors. Unless these factors are collectively resolved, the implementation process will never materialize. This explains why Rogan and Grayson (2003), assert that many visionary and educationally sound ideas and policy documents are much slower and more difficult to be implemented than usually anticipated. Although most curriculum are evaluated after every ten (10) years (Pietarinen et al.,2017; Sivekind and Westbury, 2016), the Social Studies curriculum for Colleges of Education has been in operation for over fifteen years without any significant review and change. It was only recently that it was re-aligned to conform to the basic school's 
Social Studies content. The re-alignment involves the synchronization of the Junior High School (JHS) Social Studies curriculum with that of the Colleges of Education Social Studies curriculum. The main area that was affected was the part for Governance, Politics and Stability. The synchronization was done by the Department of Arts and Social Sciences Education (DASSE); University of Cape Coast.

Process evaluation of a curriculum is done in terms of observing and recording classroom infrastructural activities and dynamics. It focuses on and examines instructional methods and strategies adopted by tutors to impact knowledge, assess students' performance and interaction between tutors and students in class. Process evaluation thus, involves enactment of the curriculum in the classroom context. Feedback from the extent to which the objectives of the curriculum are being achieved informs stakeholders on decisions to take to reform the curriculum. However, process evaluation which actually concerns the enactment of the curriculum in the classroom is least emphasized to the detriment of the students. It is against this background that this study was carried out to evaluate the on-going Social Studies curriculum in Colleges of Education in Ghana in terms of its pedagogical approaches and classroom dynamics.

\subsection{Significance of the Study}

The essence of the achievement of curriculum objectives depends on its evaluation process. Curriculum development and evaluation is a continuous process and necessary changes are part of the process in order to make it more responsive to changing demands to ensure its relevance. It is envisaged that the outcome of this study will positively impact on Social Studies students and tutors of colleges of education since the classroom dynamics would yield the expected outcomes for national curriculum development. Again, it is envisaged that the findings of the study will bring to light what really transpires in the classrooms to enable the National Council for Curriculum and Assessment (NaCCA), and the Ministry of Education think creatively and innovatively on alternative decisions to modify the existing curriculum. Finally, it adds to existing literature and can be used as a base for further research.

\subsection{Literature Review}

In reviewing literature for this study, the following sub-themes were used. Conceptual framework; pedagogical approaches in instructional process; and teacher and student behaviours which enhance instructional process in the classroom.

\subsubsection{Conceptual Framework}

Process evaluation of the Social Studies curriculum focuses on instructional activities in the teaching and learning process (classroom dynamics). Once a curriculum is developed and implemented it becomes an ongoing process hence the curriculum, teacher and programme evaluation become the main components of process evaluation (Print, 1993). Curriculum process evaluation intends to delineate, obtain and provide useful information about what is going on in the classroom, so that alternative decisions can be made to maintain, modify or terminate the instructional strategies. This study thus adopted Stufflebeam's (2003) CIPP 


\section{Macrothink}

model of curriculum evaluation as shown below.

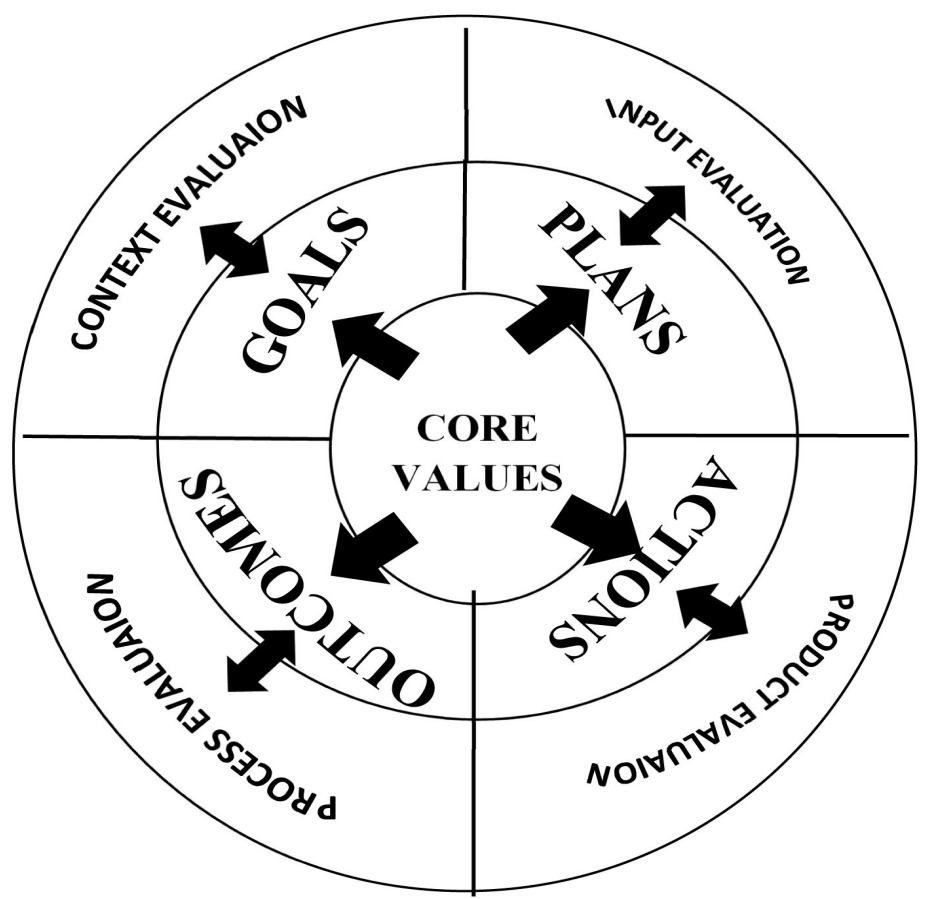

Figure 1. Conceptual framework.

Source: Adopted from Stufflebeam (2003), CIPP model of curriculum evaluation

In the first place, distinction can be made according to different curriculum contexts, for example, general (elementary and secondary) education, vocational education, higher education, adult education, and corporate training (in business and industry). A second aspect concerns the nature of curriculum activities (Walker, 1990); 'generic' (aimed at a large variety of instructional practices in diverse settings, in the Dutch situation usually at a national scale) or 'site-specific' (focused on a specific setting, for example, a school or training department). The third aspect is that, one may emphasize the type of curriculum at stake (Walberg and Haertel, 1990); products (courses, textbooks, lesson materials; usually focused on planning and delivery of concrete instructional processes), or programmes (broader educational proposals and plans for study, somewhat more distant from the direct instructional process, and embedded in more general educational policies). Fourth, evaluation activities can be characterized along the well-known distinction between formative purposes (aimed at improvement during development) or summative goals (studying curriculum quality to provide information for decision making, especially at policy levels).

To service the needs of decision makers, the Stufflebeam model provides a means for generating data relating to four stages of programme operation: context evaluation, which continuously assesses needs and problems in the context to help decision makers determine goals and objectives; input evaluation, which assesses alternative means for achieving those goals to help decision makers choose optimal means; process evaluation, which monitors the processes both to ensure that the means are actually being implemented and to make the 
necessary modifications; and product evaluation, which compares actual ends with intended ends and leads to a series of recycling decisions. During each of these four stages, specific steps are taken. They are; the kinds of decisions are identified, the kinds of data needed to make those decisions are identified, those data are collected, the criteria for determining quality are established, the data are analyzed on the basis of those criteria and the needed information is provided to decision makers (Glatthorn; 1987).

Stufflebeam's CIPP model was all about taking an informed decision on curriculum implemented. If an implemented curriculum is not living up to the expected objectives and goals, alternative means available can be used to make modifications necessary to attain the expected objectives and goals. The context, input, process, product (CIPP) model, as it has come to be called, has several attractive features for those interested in curriculum evaluation. Its emphasis on decision making seems appropriate for administrators concerned with improving curricula. Its concern for the formative aspects of evaluation remedies a serious deficiency in the Tyler model. Finally, the detailed guidelines and forms created by the committee provide step-by-step guidance for users.

Finally, curriculum evaluation may be a direct activity itself, or it may be an important aspect of some research project in the curriculum domain, in which curriculum evaluation is part of a research design aimed at answering a more fundamental research question. Since this current study does not intend to offer a full description of all possible contexts, the description in this section will be limited to the organizational characteristics of the kind of curriculum evaluation research that has been most frequent and is most accessible via publications: evaluation in the context of generic curriculum development for subjects domains in general education, especially Social Studies curriculum.

Most authors including (Kelly, 2009; Eisner, 2002; Stufflebeam, 2000) argue that curriculum evaluation refers to the processes used to weigh the relative merits of those educational alternatives which at any given time are deemed to fall within the domain of curriculum practice. In this process, evaluation is seen simply as measuring of teaching in terms of pupils learning. McKimm (2007) looks at evaluation in the context of teaching and learning; as a system of feedback providing information to planners, teachers, students, parents and decision-makers. It is a process involving ongoing activities aimed at gathering timely information about the quality of a programme. Therefore, it is a process of judging, putting a value or assessing the worth of the learning experiences. But, why do we need to evaluate our education courses and/or programmes?

To identify successes and failures of the curriculum with a view to correcting deficiencies, to measure if stated objectives have been or are being achieved, to assess if the curriculum is meeting the needs of learners and community and to measure the cost effectiveness of the curriculum.

\subsubsection{Pedagogical approaches in instructional process}

In the teaching and learning process of Social Studies, our understanding of the content and the pedagogical approaches used in the process within a larger structural framework can help 
teacher educators prepare prospective teachers with the knowledge and skills they need to achieve pedagogical balance in their practice. More significantly, most teacher educators and researchers espouse constructivist teaching methods (Alazzi, 2008; Yilmaz, 2008). However, what progressive educators see as memorable student-centered learning opportunities that inspire students to think critically and develop a love of Social Studies (Dicamillo, 2010), traditional educators often see as an amalgam of ill-structured activities that lack the content that students need to become knowledgeable citizens (Ravitch, 2003; Rochester, 2003). Many who favour traditionalist methodology point to progressive constructivist teacher education as a major reason for low performance on assessments of Social Studies knowledge by students (Leming, 2003; Schug, 2003). Yet, these methods are found in relatively few classrooms. In spite of the efforts of teacher educators, constructivist methods do not consistently transfer to classrooms the classrooms for which they are intended (Hollingsworth, 1989). Instead, new teachers, regardless of their teacher preparation programme, often follow a "pattern of teachers transmitting information to students who are then asked to reproduce it" (Newmann, 1991, p. 324). Regardless of the preparation many teachers have received, they teach Social Studies in a manner focusing more on content coverage than on the processes of thinking.

In response to this and other issues, scholars have come out with some pedagogical approaches to teaching and learning of Social Studies. Examples of such approaches are the educational philosophies such as experience-based and child-centered education. This promoted the development of thinking processes known as progressive education (Folsom, 2009). Traditional pedagogy also known by the terms "scientific and behaviourist" came into place as another pedagogical approach to the teaching and learning of Social Studies in schools and colleges. Teacher-centered and direct-instruction are other terms used to describe traditional pedagogy (Schug, 2003). These educators hold a traditional view of teaching; they maintain that there is a specific body of content knowledge that must be imparted to students (Brooks and Brooks, 1993). Traditional pedagogy is often described as transmission teaching where the learner is a more passive recipient of information than in constructivist teaching (Darling-Hammond, 1997).

In conclusion, learning content through doing and thinking is not a new idea. Long before constantly-streaming, self-produced media became ubiquitous, learning academic content through doing and thinking were clearly described by educators (Beyer, 2008; Boyle-Baise and Goodman, 2009). In addition, those in the field of psychology have provided voluminous support for the active, hands-on, minds-on learning and teaching of content that lie at the heart of progressive constructivist teaching (Bandura, 1993; Sternberg, 1997; Vygotsky, 1994). There is no shortage of research, materials, and suggestions for teaching Social Studies in ways that integrate doing and thinking with content (Levstik and Barton, 2000; Parker, 2010). Yet, notwithstanding the availability of such resources, the subject of Social Studies itself is sorely neglected or poorly taught in many of our schools.

\subsubsection{Teacher and Student Behaviours which enhance classroom Instructional process}

The positive and negative behaviours exhibited by teachers and students determine to a great extent their effectiveness in the classroom and, ultimately, the impact they have on student's 
achievement. Several specific characteristics of teacher responsibilities and teacher behaviours have contributed directly to effective teaching in the classroom. Effective teachers have a sense of how each student is doing in the classes that they teach. They use a variety of formal and informal measures to monitor and assess their pupils' mastery of a concept or skill. When a student is having difficulty, the teacher targets the knowledge or skill that is troubling the student and provides remediation as necessary to fill in that gap. Monitoring student progress and potential need not be solely the responsibility of the teacher; indeed, an effective teacher facilitates students' understanding of how to assess their own performance.

Furthermore, Quashigah, Eshun and Mensah, (2013), also assert that "the pedagogical content knowledge of Social Studies teachers does influence the way they assess their lessons." This assertion is supported by (Bekoe and Eshun, 2013), that "the background knowledge of Social Studies teachers is built from their training institutions and this goes to influence the way they teach (that is selection of content, unit or topic, formulation of objective(s), mode of teaching, and assessment tool used)." As a result of this, implementers of Social Studies curriculum need to be abreast with how the subject is taught and assessed. Bekoe, Eshun and Bordoh (2013) however, stressed that "due to the hasty nature in formulating formative assessment and scoring, tutors place emphasis on cognitive domain to the neglect of affective and psychomotor domains which are also of paramount importance." With this, much is needed to assist Social Studies teachers to be abreast with the nature and the content of Social Studies in a harmonized subject matter required to improve the quality of teaching and learning (Bekoe and Eshun, 2013). Poor attitudes of learners to learning and bad study habits may lead to uncommitted attitudes of teacher to teaching: instability in schools occasioned by teacher, students unrest and the frequent closure of schools due to inability of the government to meet its financial obligation.

Shulman (1987), also opines that teachers need to understand the subject matter deeply and flexibly so as to help students create useful cognitive maps, relate one idea to another as well to address their misconceptions. In his contribution to the scholarship of teacher knowledge, Shulman states that teachers need to master three types of knowledge, namely content knowledge also called "deep" knowledge of the subject itself, pedagogical content knowledge which is a special blend of content and pedagogy that is exclusive to teachers as a special form of understanding how best to teach a specific content and thirdly, knowledge of the curriculum development termed as curriculum knowledge. Shulman (1987), also identified the following types of knowledge that must be possessed by teachers; general pedagogical knowledge (or generic teaching principles), knowledge of educational context or human relations, knowledge of the learner and their characteristics as well as knowledge of educational ends, purpose, values, and their philosophical and historical backgrounds. This demonstrates that the innate quality of the teacher does ultimately over-ride its importance. It is widely accepted among researchers that the quality of our schools cannot be higher than the quality of teachers in them and that the quality of our teachers in the schools is also dependent upon high quality teacher education and professional development opportunities. Thus, teachers who are well-prepared in traditional teacher education programmes and continue in-service education help ensure increased levels of student achievement which is 
one of the indicators of successful curriculum implementation (Darling-Hammond, 2000).

\subsection{Objectives of the Study}

The general objective of the study was to undertake a process curriculum evaluation of the current Social Studies curriculum of the Colleges of Education in Ghana. Specifically, examining tutor pedagogical approaches in the Social Studies instructional process; and assess classroom dynamics in the instructional process in terms of tutor and student behaviour.

The study was guided by the following research questions.

1) What are the pedagogical approaches used by tutors in the Social Studies instruction delivery?

2) Which Tutor and student behaviours significantly enhance the Social Studies instructional process in the classroom?

\section{Method}

The research design used for the study was the descriptive survey; adopting, both quantitative and qualitative methods. The qualitative methods (structured interview) were viewed to make up for any weaknesses inherent in the use of close-ended questionnaires of quantitative method. The mixed method approach was used to bridge the qualitative and quantitative methods to generate more inclusive results than either method in isolation. The researchers hope to show that quantitative methods such as questionnaire are valuable to test the relative importance of qualitatively informed ideas. Mixed method designs integrate both qualitative and quantitative approaches to data collection and analysis. Mixed method approach to research has the advantage and potential to offer more comprehensive understanding of complex processes and issues as well as collaborate findings.

The weaknesses of qualitative and quantitative approaches can be offset by the strengths of both approaches. Words can add meaning to numbers and numbers can add precision to words (Johnson and Onwuegbuzie, 2004). The study was limited to four Colleges of Education in Ghana, namely Accra, Ada, Presbyterian College of Education and the Presbyterian Women's College in Aburi.

\subsection{Sample and Sampling Procedure}

The target population for the study comprised all Social Studies tutors and teacher trainees in the Colleges of Education in Ghana. For fair representation of both the colleges and sex groups, stratified sampling was seen as the main sampling technique for the Social Studies teacher trainees. They were put into strata (groups) as colleges and into further consideration as males and females. A proportionate stratified sample of fifty per cent (50\%) was employed for each college and $50 \%$ for each sex in each college. Simple random sampling was then applied to select respondents from each stratum (group) for the actual number of Social Studies teacher trainees for the study. In Accra College of Education, 50\% of the two hundred (200) males produced one hundred (100) respondents and 50\% of the females produced 55 
respondents. In Ada College of Education, $50 \%$ of the males produced 30 respondents and the females produced 22 respondents. Presbyterian College of Education produced 95 males and 80 females. The Presbyterian Women's College in Aburi produced 98 respondents. In all, a sample size of four hundred and eighty (480) Social Studies teacher trainees was chosen for the study, representing 50\% of the target population of 961 Social Studies teacher trainees in the four selected colleges of education. The data collection tools that were used to collect data for the study was semi-structured interview guide and questionnaire.

The researchers did pre-testing of the instruments by using five Social Studies tutors and 60 Social Studies teacher trainees from Wesley College of Education. The reason for pre-testing the instruments was to ascertain the validity and reliability of the instruments. It also gave the advance warnings about where the main research project could fail, where research protocols might not be followed, or whether proposed methods or instruments were inappropriate or too complicated.

Finally, it was pre-tested mainly to improve the internal validity of the instruments. The Cronbach alpha values for the pre-test were 0.83 and 0.83 for the first and second set of the questionnaires respectively. This co-efficient could be considered high because, according to Fraenkel and Wallen (2000), reliability co-efficient of .70 is seen to be highly reliable for research purpose. The questionnaires were personally administered by the researchers to the teachers. The respondents were assured of confidentiality, anonymity of information given and guaranteed that information provided would only be used for academic purpose. The qualitative data analysis therefore involved gaining comprehensive understanding and analytical descriptions of statements made by respondents. The written and recorded data were transcribed and put into various themes for easy analysis. The descriptive statistics was used to analyze the research questions.

\section{Results and Discussion}

This section deals with the presentation and discussion of the results that were drawn from the data collected in order to find answers to the research questions. The results were presented in simple frequencies, percentages, means, and standard deviation. The results are discussed in relation to the research questions as well as the literature review.

\subsection{Research Question 1: Pedagogical approaches used by tutors in the Social Studies instruction delivery}

The pedagogical approaches used by tutors in the process of curriculum implementation and evaluation are very important in helping us to achieve the objective of the curriculum. To achieve this, research question 1 sought to find out the pedagogical approaches used by tutors in Social Studies instructional delivery. The respondents were asked to indicate the extent to which they agree with the statement using the following; Always, Sometimes and Never. Table 1 illustrates their responses. 
Table 1: Pedagogical approaches used by tutors in the Social Studies instruction delivery

\begin{tabular}{llcc}
\hline \multirow{2}{*}{ Statement } & \multicolumn{3}{c}{ Responses } \\
\cline { 2 - 4 } & $\begin{array}{c}\text { Always } \\
\%\end{array}$ & $\begin{array}{c}\text { Sometimes } \\
\%\end{array}$ & $\begin{array}{c}\text { Never } \\
\%\end{array}$ \\
\hline $\begin{array}{l}\text { Teachers use large and small group } \\
\text { discussions in teaching }\end{array}$ & 41.7 & 33.3 & 25.0 \\
\hline Use of cooperative and individual learning & 45.8 & 29.2 & 25.0 \\
\hline Use of role-play and individual presentations & 37.5 & 33.3 & 29.2 \\
\hline Teachers give project work to students & 75.0 & 20.8 & 4.2 \\
\hline Use of fieldtrip approach & 25.0 & 25.0 & 50.0 \\
\hline Activity and student-centred approach & 62.5 & 33.3 & 4.2 \\
\hline Students N-480
\end{tabular}

Students N=480 Source: Field data, 2019

The statistics from Table 1 revealed that, the majority of the respondents $75.0 \%$ agreed that tutors always give project work to students, $20.8 \%$ said sometimes and $4.2 \%$ said they never used it. On the use of activity and student-centred approach in teaching Social Studies, $62.5 \%$ of the respondents said the tutors always used it, 33.3\% said sometimes and $4.2 \%$ said the tutors never used it. Again, $41.7 \%$ of the respondents said their tutors always used large and small group discussions in teaching, 33.3\% said the tutors never used it and $25.0 \%$ said they used the approach. Similarly, $45.8 \%$ of the respondents said tutors always used cooperative and individual learning in Social Studies lesson delivery, $29.2 \%$ said sometimes and $25.0 \%$ tutors never used cooperative and individual learning in Social Studies lesson delivery. Concerning the use of field trip in teaching, 50\% of the students said their tutors never used it and $25.0 \%$ responded that they used it always, and sometimes.

Relating this to the literature, Erickson (2007), posits that, large or small group discussion, cooperative or individual learning, role-play or individual presentations are structural processes teachers use in the classroom. Folsom's (2009), finding that one of the pedagogical approaches to the effective teaching and learning process is the experience-based, child-centered education that promotes the development of thinking processes known as progressive education supports the results of the study. Folsom's (2005), finding is also in line with this that when teachers grasp these pedagogical approaches to teaching and largely invisible processes of learning, they can consciously plan questions and learning activities that help students develop their thinking and emotional processes as they are learning content.

When the tutors, subject specialists and curriculum experts were interviewed on the issue of the pedagogical approaches used by tutors in Social Studies instructional delivery, it was revealed that most of the tutors used appropriate pedagogical approaches to the effective teaching and learning of Social Studies. Most of the tutors used constructive methods in the running and management of their daily activities and implementing the curriculum. The tutors also used more new and innovative methods for effective teaching and learning in lessons delivery. One of the respondents gave the following response from the interview;

"Look, you see there is no need denying the fact that use of appropriate teaching pedagogies plays very crucial role in the teaching and learning process. So, tutors who are involved in the 
delivering of knowledge, skills and information in the colleges of education all use these new and innovative pedagogical approaches you are referring to as progressive constructivist teaching".

Another respondent (tutor) was interviewed on the pedagogical approaches used by tutors in the Social Studies instruction delivery in the teaching and learning process. This was the response.

"Sometimes it is good to let people know the benefits we get from the use of appropriate pedagogical approaches in the teaching and learning process. It makes teaching and learning more easily and simplified. We give students assignments and projects and they complete on their own. This helps them to equip themselves with skills in searching for right information and content knowledge of what they do. Through the use of these pedagogical approaches, students getting access to various kinds of information for teaching and learning has become easy. Teachers should adopt a modern way of teaching and learning. You see, what I am particularly worried about is that some of the institutions do not have modern facilities for the adoption and effective implementation of the curriculum".

The results show that, the use of appropriate pedagogical approaches in teaching played important roles in the teaching and learning process. The findings agreed with that of Russell (2010), who found that Social Studies provides opportunities for learning content through project work where students can express their creativity while at the same time, develop the critical thinking skills of decision making, planning, and self-evaluation. Yet, too often, Social Studies is taught in a way that is anything but the passionate, memorable subject it could be.

3.2 Research Question 2: Tutor and student behaviours which significantly enhance the Social Studies instructional process in the classroom

The researchers were interested in finding out from the respondents, the tutor and student behaviours which significantly enhance the Social Studies instructional process in the classroom. The result is illustrated in Table 2. 
Table 2. Tutor and student behaviours which significantly enhance the Social Studies instructional process in the classroom

\begin{tabular}{lllll}
\hline & \multicolumn{4}{c}{ Responses } \\
\cline { 2 - 5 } Statement & SA & A & D & SD \\
\hline $\begin{array}{l}\text { The pedagogical content knowledge of } \\
\text { Social Studies teachers }\end{array}$ & 50.0 & 40.0 & 10.0 & 0.0 \\
\hline $\begin{array}{l}\text { Background knowledge of Social Studies } \\
\text { teachers }\end{array}$ & 50.0 & 39.6 & 10.4 & 0.0 \\
\hline Mode of assessing students by tutors & 45.8 & 20.8 & 18.8 & 14.6 \\
\hline Poor attitudes of learners to learning & 18.8 & 20.8 & 45.8 & 14.6 \\
\hline Bad study habits of students & 18.8 & 20.8 & 35.8 & 24.6 \\
\hline Uncommitted attitudes of teacher to teaching & 25.0 & 10.0 & 65.0 & 0.0 \\
\hline $\begin{array}{l}\text { Teachers' attitudes towards } \\
\text { Social Studies education }\end{array}$ & 50.0 & 39.6 & 10.4 & 0.0 \\
\hline Teachers teaching-learning strategies & 50.0 & 40.0 & 10.0 & 0.0 \\
\hline Source: Fidd data, 2019 Students & & & & \\
\hline
\end{tabular}

Source: Field data, $2019 \quad$ Students N=480

The study further revealed from Table 2 that $90 \%$ of the respondents agreed that the pedagogical content knowledge of Social Studies teachers, teachers' teaching-learning strategies significantly enhanced the Social Studies instructional process in the classroom. Also, $89.6 \%$ of the respondents agreed that background knowledge of Social Studies teachers, and teachers' attitudes towards Social Studies education significantly enhanced the Social Studies instructional process in the classroom. This result supports the view of Quashigah, Eshun and Mensah (2013), who assert that the pedagogical content knowledge of Social Studies teachers does influence the way they assess their lessons. This assertion is supported by Bekoe and Eshun (2013), that the background knowledge of Social Studies teachers is built from their training institutions and this goes to influence the way they teach (that is selection of content, unit or topic, formulation of objective(s), mode of teaching, and assessment tool used). As a result of this, implementers of Social Studies curriculum need to be abreast with how the subject is taught and assessed.

Shulman (1987), also supports this view when he opines that teachers need to understand the subject matter deeply and flexibly so as to help students create useful cognitive maps, relate one idea to another as well to address their misconceptions. In his contribution to the scholarship of teacher knowledge, Shulman states that teachers need to master three types of knowledge, namely content knowledge also called "deep" knowledge of the subject itself, pedagogical content knowledge which is a special blend of content and pedagogy that is exclusive to teachers as a special form of understanding how best to teach a specific content and thirdly, knowledge of the curriculum development termed as curriculum knowledge. Shulman (1987), also identified the following types of knowledge that must be possessed by teachers; general pedagogical knowledge (or generic teaching principles), knowledge of educational context or human relations, knowledge of the learner and their characteristics as well as knowledge of educational ends, purpose, values, and their philosophical and historical backgrounds. This demonstrates that the innate quality of the teacher does ultimately 
over-ride in importance.

\section{Conclusions}

From the findings of this study, the following conclusions were made.

It was revealed that most of the tutors used appropriate pedagogical approaches to the effective teaching and learning of Social Studies. The study concluded that the use of appropriate pedagogical approaches in teaching played important roles in the teaching and learning process.

The study revealed that majority of the respondents agreed that the pedagogical content knowledge of Social Studies teachers and teachers' teaching-learning strategies significantly enhanced the Social Studies instructional process in the classroom. It can be concluded that pedagogical content knowledge of Social Studies teachers helped in curriculum implementation and evaluation process.

\subsection{Recommendations}

Based on the findings of the study and the conclusions that have been drawn, the following recommendations are made regarding Social Studies curriculum.

1. Teacher training institutions, teacher education division, and universities in Ghana should give appropriate training to teachers in their subject areas to improve upon their pedagogical skills and knowledge.

2. From the findings of the study, Social Studies teachers should try as much as possible to integrate the use of different teaching and learning methods in teaching to improve the quality of instruction given in schools and also ensure the use of standard student-centered approach method of teaching as against teacher centered which teachers currently employ in teaching.

\subsection{Suggestions for Further Studies}

It must be emphasized that this study forms part of similar researches that have been conducted in different areas. Taking into consideration its limitations, the researchers wish to suggest that further research should be conducted on "Teachers' attitude towards the use of teaching and learning resources in teaching Social Studies in the colleges of education in Ghana".

\section{Acknowledgement}

We would like to thank the reviewers and editor for providing valuable suggestions to improve this paper.

\section{References}

Alazzi, K. F. (2008). Teachers' perceptions of critical thinking: A study of Jordanian secondary school Social Studies teachers. The Social Studies, 99(6), 243-249. https://doi.org/10.3200/TSSS.99.6.243-248

Bandura, A. (1993). Perceived self-efficacy in cognitive development and functioning. 
Educational Psychologist, 28(2), 117-148. https://doi.org/10.1207/s15326985ep2802_3

Bekoe, S. O., \& Eshun, I. (2013a). Curriculum feuding and implementation challenges: The case of Senior High School (SHS) Social Studies in Ghana. Journal of Education and Practice, 4(5), 39-45.

Bekoe, S. O., Eshun, I. \& Bordoh, A. (2013). Formative assessment techniques tutors use to assess teacher-trainees' learning in Social Studies in Colleges of Education in Ghana. Research on Humanities and Social Sciences, 3(4), 20-30.

Beyer, B. K. (2008). What research tells us about teaching thinking skills. The Social Studies, 99(5), 223-232. https://doi.org/10.3200/TSSS.99.5.223-232

Boyle-Baise, L., \& Goodman, J. (2009). The influence of Harold O. Rugg: Conceptual and pedagogical considerations. The Social Studies, 100(1), p. 31-41. https://doi.org/10.3200/TSSS.100.1.31-40

Brooks, J. G., \& Brooks, M. G. (1993). In search of understanding: The case for constructivist classrooms. Alexandria, VA: Association for Supervision and Curriculum Development.

Cronbach, L. J. (1963). Course improvement through evaluation. Teachers College Record, $64,672-83$.

Cronbach, L.J. (1963) Course Improvement Through Evaluation. In Stufflebeam, D.L., Madaus, G.F Kellaghan, T. (Eds.) 2000. Evaluation Models: Viewpoints on Educational and Human Services Evaluation. Boston: Kluwer Academic Publishers.

Darling-Hammond, L. (1997). The right to learn: A blueprint for creating schools that work. San Francisco: Jossey-Bass.

Dicamillo, I. (2010). Linking teaching for understanding to practice in a U. S. history class. The Social Studies, 101(1), 10-17. https://doi.org/10.1080/00377990903284088

Eisner, E. W. (2002). From episteme to phronesis to artistry in the study and improvement of teaching. Teaching and Teacher Education, 18, 375-385. https://doi.org/10.1016/S0742-051X(02)00004-5

Folsom, C. (2005). A model for preparing teachers in a changing world: Teaching for intellectual and emotional learning (TIEL). Teacher Education and Practice, 8(4), 471-487

Fraenkel, J. R., \& Wallen, N. E. (2000). How to design and evaluate research in education. McGraw-Hill: Boston

Fullan, M. \& Stiegelbauer, S. (2000). The new meaning of educational change (2 ${ }^{\text {nd }}$ edn.). Britain: Cassell Educational Ltd. https://doi.org/10.4324/9780203986561

Fullan, M. (1991). Curriculum implementation. In Lewy, A. (Ed.), International encyclopaedia of curriculum. Oxford: Pergamon Press.

Fullan, M. (2001). The new meaning of educational change (3rd ed.). New York: Teachers 
College Press. https://doi.org/10.4324/9780203986561

Glathorn, (1987). Curriculum leadership. Glenview, IL: Scott, Foresman Goodson, I. (Ed.) (199). Social histories of the secondary curriculum; subjects for study. London; Falmer.

Hollingsworth, S. (1989). Prior beliefs and cognitive change in learning to teach. American Educational Research Journal, 26(2), 160-189. https://doi.org/10.3102/00028312026002160

Leming, J. S. (2003). Ignorant activists: Social change, "higher order thinking," and the failure of Social Studies. In J. Leming, L. Ellington, \& K Porter-Magee (Eds), Where Did Social Studies Go Wrong? Retrieved from http://www.edexcellence.net/doc/ContrariansFull.pdf

Levstik, L. S., \& Barton, K. C. (2000). Doing history (2nd edn.). New York: Routledge.

Martorella, P. (1985) Elementary Social Studies: Development reflective, competent and concerned citizens. Boston: little brown company.

Martorella, P. H. (1994). Social Studies for elementary school children. New Jersey: Prentice Hall Inc.

McKimm, J. (2007). Curriculum Design and Development, Unpublished Lecture Notes. School of Medicine Imperial College Centre for Education.

MOE (2005). Teacher's guidebook for social studies; Grade five [In Arabic]. Muscat: Author.

Newmann, F. M. (1991). Promoting higher order thinking in Social Studies: Overview of a study of 16 high school departments. Theory and Research in Social Education, 19(4), 324-340. https://doi.org/10.1080/00933104.1991.10505645

Odumah, L. (2003). Foundations of social studies. An unpublished pamphlet.

Parker, W. C. (2010). Social Studies today. New York: Routledge. https://doi.org/10.4324/9780203841273

Pietarinen, J., Pyhältö, K. \& Soini, T. (2017). Large-scale curriculum reform in Finland -exploring the interrelation between implementation strategy, the function of the reform, and curriculum coherence. The Curriculum Journal, 28(1), 22-40.

Print, M. (1993). Curriculum Development and Design, (2 ${ }^{\text {nd }}$ edn.). St. Leonards, NSW: Allen and Unwin

Quashigah, A. Y., Eshun, I., \& Mensah, M. F. (2013). Influences of the pedagogical content knowledge of graduate Social Studies teachers on questions they set in Senior High Schools in Ghana. Research on Humanities and Social Sciences, 3(6), 76-86.

Ravitch, D. (2003). A brief history of Social Studies. In J. Leming, L. Ellington \& K. Porter (Eds.), Where did Social Studies go wrong? (pp. 1-5). (ERIC Document Reproduction Service No. ED481631).

Rochester, J. M. (2003). The training of idiots: Civic education in America's schools. In J. 
Leming, L. Ellington \& K. Porter (Eds.), Where did Social Studies go wrong? (pp. 6-39). (ERIC Document Reproduction Service No. ED481631)

Rogan, J. M. \& Grayson, D. J. (2003). Towards a theory of curriculum implementation with reference to science education in developing countries. International Journal of Science Education, 25 (10), 1171-1204.

Ruiz-Primo, M. A. (2006). A multi-method and multi-source approach forstudying fidelity of implementation: CSE Report 677. Los Angeles, CA: Stanford University.

Schug, M. C. (2003). Teacher-centered instruction: The Rodney Dangerfield of Social Studies. In J. Leming, L. Ellington, \& K Porter-Magee (Eds), Where Did Social Studies Go Wrong? (pp.94-110). Retrieved from the Thomas B. Fordham Institute website http://www.edexcellence.net/doc/ContrariansFull.pdf

Shulman, L. S. (1987). Knowledge and teaching: Foundations of the new reform. Harvard Educational Review, 57 (1), 1-22. https://doi.org/10.17763/haer.57.1.j463w79r56455411

Siveskind, K. \& Westbury, I. (2016). State-based curriculum work and curriculum-making: Norway's læreplanverket 1997. Journal of Curriculum Studies, 48 (6), 766 -782

Sternberg, R. J. (1997). Educating intelligence: Infusing the triarchic theory into school instruction. In R. J. Sternberg \& E. Grigorenko (Eds.), Intelligence, heredity, and environment (pp. 343-362). New York: Cambridge University Press. https://doi.org/10.1017/CBO9781139174282.013

Stufflebeam, D. L. (2000a). Foundational Models for 21st Century Program Evaluation. In Stufflebeam, D.L., Madaus, G.F Kellaghan, T. (Eds.) 2000. Evaluation Models: Viewpoints on Educational and Human Services Evaluation. Boston: Kluwer Academic Publishers.

Stufflebeam, D. L. (2000b). The CIPP Model for Evaluation. In Stufflebeam, D.L., Madaus, G.F Kellaghan, T. (Eds.) 2000. Evaluation Models: Viewpoints on Educational and Human Services Evaluation. Boston: Kluwer Academic Publishers.

Stufflebeam, D. L. (2002). CIPP Evaluation Model Checklist. Retrieved from http://www.wmich.edu/evalctr/checklists on 8th November 2014

Stufflebeam, D. L. (2003). The CIPP Model for Evaluation. Paper presented at the Annual Conference of the Oregon Program Evaluators Network, Portland, Oregon. Retrieved from http://www.wmich.edu/evalctr/pubs/CIPP-ModelOregon10-03.pdf. on 10th March 2014

Stufflebeam, D. L., \& Shinkfield, A. J. (2007). Evaluation theory, models, \& applications. San Francisco, CA: Jossey-Bass. https://doi.org/10.1007/978-94-010-0309-4_4

Vygotsky, L. S. (1994). Thought and language. Cambridge, MA: MIT Press.

Walker, D. (1990). Fundamentals of Curriculum. Fort Worth, TX: Harcourt Brace.

Yilmaz, K. (2008). Social Studies teachers' views of learner-centered instruction. European Journal of Teacher Education, 31(1), 35-53. https://doi.org/10.1080/02619760701845008 